\title{
Crosstalk between EGFR and TrkB enhances ovarian cancer cell migration and proliferation
}

\author{
LIHUA QIU $^{1,2}$, CHANGLIN ZHOU $^{1}$, YUN SUN $^{1,2}$, WEN DI $^{1}$, ERICA SCHEFFLER $^{2}$, \\ SARAH HEALEY ${ }^{2}$, NICOLA KOUTTAB ${ }^{3}$, WENMING CHU ${ }^{4}$ and YINSHENG WAN ${ }^{2}$ \\ ${ }^{1}$ Department of OB/GYN, Renji Hospital, Shanghai Jiaotong University, Shanghai 200001, P.R. China; \\ ${ }^{2}$ Department of Biology, Providence College, Providence, RI 02918; ${ }^{3}$ Department of Pathology, \\ Roger Williams Medical Center, Boston University, Providence, RI 02908; ${ }^{4}$ Department of \\ Molecular Microbiology and Immunology, Brown University, Providence, RI 02903, USA
}

Received March 16, 2006; Accepted May 17, 2006

\begin{abstract}
Ovarian cancer remains the leading cause of fatality among all gynecologic cancers, although promising therapies are in the making. It has been speculated that metastasis is critical for ovarian cancer, and yet the molecular mechanisms of metastasis in ovarian cancer are poorly understood. Growth factors have been proven to play important roles in cell migration associated with metastasis, and inhibition of growth factor receptors and their distinct cell signaling pathways has been intensively studied, and yet the uncovered interaction or crosstalk among various growth factor receptors complicates this otherwise promising approach. We investigated the crosstalk between EGFR and TrkB, both of which have been known to be important in cell survival and migration in response to EGF and BDNF. Our results showed that both EGF and BDNF induced cell migration and cell proliferation in cultured human ovarian cancer cells (Caov3 cell line). EGF and BDNF transactivated TrkB and EGFR respectively, and activated downstream cell survival components such as Akt. EGFR and TrkB kinase inhibitors inhibited EGF- and BDNF-induced TrkB and EGFR activation and Akt phosphorylation, and cell proliferation and migration. Using EGFR knockout cells, we further demonstrated that EGFR is required for EGF-induced cell migration. Collectively, our data indicate that EGFR and TrkB crosstalk each other in response to EGF and BDNF, leading to cell survival pathway activation in ovarian cancer cells. Our data suggest that a
\end{abstract}

Correspondence to: Dr Wen Di, Department of OB/GYN, Renji Hospital, Shanghai Jiaotong University, Shanghai 200001, P.R. China

E-mail: diwen163@163.com

Dr Yinsheng Wan, Department of Biology, Providence College, 549 River Ave., Providence, RI 02918, USA

E-mail: yswan@providence.edu

Key words: EGFR, tyrosine kinase B, ovarian cancer, Akt combination of inhibitors of both receptors with cell survival pathway inhibitors would provide a better outcome in the clinical treatment of ovarian cancer.

\section{Introduction}

Ovarian cancer is the most frequent cause of cancer death among all gynecologic cancers, and therapies over the last 30 years unfortunately have not improved the cure rates very much (1). It has been speculated that metastasis remains the leading cause of treatment failure and death from ovarian cancer, and yet the molecular mechanisms associated with acquisition of metastatic ability in ovarian cancer are poorly understood.

Physiologically, cells of an organ stay close to home. In fact, their lives depend on it. Within their own neighborhood, they communicate to mutual benefit with the cells around them, while signals from the matrix beneath inform them that they are on home ground (2). When they lose contact with the matrix, they die, in a process named 'anoikis'. In contrast, cancer cells do not become fatally homesick if separated from home turf; in fact, the ability to leave home and survive, even thrive, in a foreign tissue is essential for them to invade and metastasize. Anoikis has been suggested to act as a physiological barrier to metastasis, resistance to anoikis may allow survival of cancer cells during systemic circulation, thereby facilitating secondary tumor formation in distant organs (2-4). Recently, it was found that tyrosine kinase B (TrkB) activation and or expression seems to allow cells to resist anoikis by rewiring their internal circuitry, and thus to metastasize (5).

Neurotrophin tyrosine kinase receptor, or TrkB, has been isolated and sequenced from several mammalian species. Its cognate ligand brain-derived neurotrophic factor or BDNF, plays important roles in regulating the survival, structure, and function of CNS neurons and peripheral nervous system (6-9). Indeed, there is increasing evidence that TrkB and BDNF are frequently overexpressed in human cancers, including pancreatic and prostate carcinoma, Wilms' tumor and neuroblastomas, particularly those with aggressive behavior and poor prognosis (10-13). Moreover, it was found 
that TrkB-BDNF pathway is associated with enhanced resistance to chemotherapy in neuroblastoma line SH-SY5Y cells $(14,15)$.

While the precise mechanism of action of TrkB remains elusive, accumulated experimental data indicate that TrkB activates phosphatidyl inositol-3-kinase (PI3K)/protein kinase $\mathrm{B}$ (PKB) and mitogen-activated protein kinase/extracellular signal-regulated kinase (MEK-ERK) signaling (14,16-20). Specific inhibition of these two TrkB signaling pathways leads to distinct biological effects. Inhibition of PI3-kinase decreases cultured embryonic cortical progenitor cell survival and improves the ability of chemotherapeutic agents to induce the death of neuroblastomas, whereas inhibition of MEK selectively blocks the generation of neurons, with no effects on survival or proliferation $(21,22)$. Furthermore, PI3K/PKB signaling activated by TrkB contributes to anoikis resistance in rat intestinal epithelial cells which are otherwise highly sensitive to anoikis (5).

Receptor tyrosine kinases of the EGFR family regulate essential cellular functions, including proliferation, survival, migration, and differentiation, and appear to play a central role in the etiology and progression of solid tumors $(23,24)$. Since EGFR is frequently overexpressed in breast, lung, colon, ovarian, and brain tumors, EGFR signaling has become an important target in anticancer drug development due to its ability to control tumor cell proliferation and to suppress apoptosis (25). Inhibiting EGFR expression and/or function in ovarian cancer cells by EGFR inhibitor, PD153035 or EGFR antisense decreases their invasive behavior (26).

We undertook the present study to investigate whether there is crosstalk between EGFR and TrkB in human ovarian cancer cells, and whether the activation of these two receptors contributes to increased migration and survival of ovarian cancer cells. The data presented demonstrate that EGF and BDNF transactivate both EGFR and TrkB pathway, leading to enhanced cell migration and survival of ovarian cancer. The data suggest that combination of EGFR and TrkB inhibitors with cell survival pathway inhibitors could provide a better outcome in the clinic treatment of human ovarian cancer.

\section{Materials and methods}

Cell culture. Human ovarian epithelial cancer cell line (Caov3 cell) was from J.Y. Lin of the University of Michigan. Mouse embryonic fibroblast (MEF) derived from $\mathrm{EGFR}^{--}$mice and its wild-type were kindly provided by Dr Zigang Dong at Hormel Institute of the University of Minnesota. Human Caov3 cells, $\mathrm{EGFR}^{+/+} \mathrm{MEF}$, and $\mathrm{EGFR}^{-/-} \mathrm{MEF}$ cells were maintained as previously described (27) in Dulbecco's modified Eagle's medium (DMEM) (Sigma) supplemented with $10 \%$ fetal bovine serum (Hyclone), penicillin/streptomycin (1:100, Sigma) and $4 \mathrm{mM} \mathrm{L-glutamine,} \mathrm{in} \mathrm{a} \mathrm{humid} \mathrm{atmosphere}$ incubator with $5 \% \mathrm{CO}_{2}$ at $37^{\circ} \mathrm{C}$. Cells were reseeded twice weekly at a density of $0.2 \times 10^{6}$ cells $/ \mathrm{ml}$ with fresh complete culture medium. Unless otherwise indicated, cultures were grown to $70-80 \%$ confluence and then serum-starved overnight in DMEM prior to treatment. When inhibitors were used, cells were pretreated for $2 \mathrm{~h}$ prior to stimulation with the indicated concentration of inhibitor, which remained in the medium for the remainder of the experiment.
Reagents. BDNF and K-252a were from EMD Biosciences, human EGF and mouse EGF were from BD Bioscience, Fibronectin and anti- $\beta$-actin were from Sigma. Anti-phosphoEGFR (Tyr1068), phospho-Tyr490, phospho-p44/42 MAP kinase, phospho-SAPK/JNK (Thr183/Tyr185), phospho-p38 MAPK (Thr180/Tyr182), phospho-Akt (Ser473), p44/42 MAP kinase, SAPK/JNK, p38 MAP kinase and Akt antibody were from Cell Signaling Technology (Beverly, MA). AntiEGFR (1005), anti-TrkB (H181), goat anti-rabbit IgG-HRP, and goat anti-mouse IgG-HRP antibody were from Santa Cruz Biotechnology (Santa Cruz, CA). PD 153035, K252a, and LY294002 were from Calbiochem. Polybeads were from Polyscience.

Treatment. EGF and BDNF solution were diluted in DMEM medium without serum to final concentrations of 100 and $50 \mathrm{ng} / \mathrm{ml}$, respectively. In the time-dependent experiments, Caov3 cells were treated with $100 \mathrm{ng} / \mathrm{ml}$ of EGF or $50 \mathrm{ng} / \mathrm{ml}$ of BDNF, and harvested at 5, 15, 30, 60, and $120 \mathrm{~min}$ after EGF and BDNF treatment. In experiments for exploration of signaling pathways, cell migration, cell proliferation, and cell survival, Caov3 cells were treated with $10,100,1000 \mathrm{ng} / \mathrm{ml}$ of EGF, or 5, 50, $500 \mathrm{ng} / \mathrm{ml}$ of BDNF for $24 \mathrm{~h}$, or with $100 \mathrm{ng} / \mathrm{ml}$ of EGF or $50 \mathrm{ng} / \mathrm{ml}$ of BDNF in the presence and absence of EGFR (PD153035, $20 \mu \mathrm{M})$, PI3K/Akt (LY294002, $50 \mu \mathrm{M}$ ) and TrkB (K252a, $200 \mathrm{nM}$ ) inhibitors for 24 and 48 h. Cell densities and morphologies were photographed post treatment.

Western blot analysis. As described previously (27), cells with and without treatment were washed with cold phosphatebuffered saline (PBS: $50 \mathrm{mM}$ phosphate, $\mathrm{pH} 7.4,100 \mathrm{mM}$ $\mathrm{NaCl}$, and $10 \mathrm{mM} \mathrm{KCl}$ ) and harvested by scraping into $0.2 \mathrm{ml}$ RIPA buffer containing $50 \mathrm{mM}$ Tris- $\mathrm{HCl}$ (pH 7.4), $150 \mathrm{mM}$ $\mathrm{NaCl}, 1 \% \mathrm{NP} 40,1 \mathrm{mM}$ EDTA, $0.25 \%$ sodium deoxycholate, $1 \mathrm{mM} \mathrm{NaF}, 10 \mu \mathrm{M} \mathrm{Na}_{3} \mathrm{VO}_{4}, 1 \mathrm{mM}$ phenylmethylsulfonyl fluoride, and protease inhibitor cocktail $(10 \mu \mathrm{g} / \mathrm{ml}$ leupeptin, $10 \mu \mathrm{g} / \mathrm{ml}$ aprotinin, and $1 \mu \mathrm{M}$ pepstatin). Cell lysates were incubated on ice for $30 \mathrm{~min}$. After centrifugation at 14,000 rpm for $10 \mathrm{~min}$ at $4^{\circ} \mathrm{C}$, protein concentration was determined by a Bio-Rad protein assay (Bio-Rad, Hercules, CA). Proteins $(50 \mu \mathrm{g})$ were denatured in 2X SDS-PAGE sample buffer for $5 \mathrm{~min}$ at $95^{\circ} \mathrm{C}$. The proteins were separated by $10 \%$ or $7.5 \%$ SDS-PAGE and eletrotransferred to Immobilon-P membrane (Millipore, Bedford, MA) for $2 \mathrm{~h}$ at $4^{\circ} \mathrm{C}$. Non-specific binding was blocked with $10 \%$ dry milk in TBST $(20 \mathrm{mM}$ Tris- $\mathrm{HCl}$, $\mathrm{pH} 7.4,137 \mathrm{mM} \mathrm{NaCl}, 0.01 \%$ Tween-20) for $1 \mathrm{~h}$ at room temperature. With constant shaking, the membranes were incubated in primary antibodies in dilution buffer $(2 \%$ BSA in TBST) overnight at $4^{\circ} \mathrm{C}$. After washing with TBST three times, the membranes were incubated in secondary antibodies at room temperature for $1 \mathrm{~h}$ with constant shaking. The expression of targeted proteins was detected by an ECL kit (Amersham Biosciences) following manufacturer's instructions and visualized by autoradiaography with Hyperfilm.

Phagokinetic track motility assay. As described previously (27), 12-well plates were placed by coating medium $(20 \mu \mathrm{g} / \mathrm{ml}$ fibronectin in PBS), and stored for at least $2 \mathrm{~h}$ at $37^{\circ} \mathrm{C}$. After removing the coating medium carefully with a Pasteur pippet, wells were washed once with PBS and $2.4 \mathrm{ml}$ microsphere 

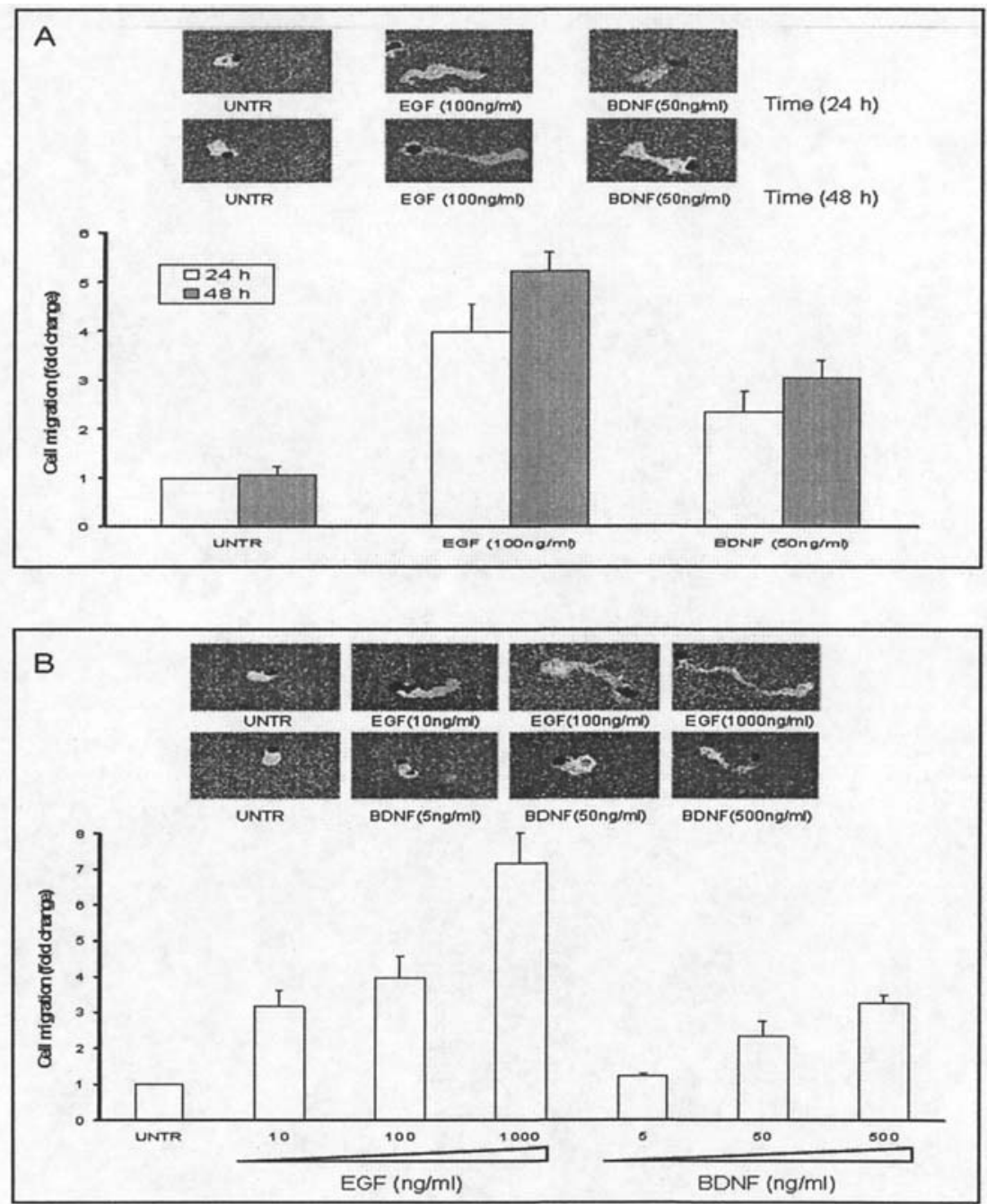

Figure 1. EGF and BDNF induce cell migration in human Caov3 cells. Cells were seeded in 12-well plates and treated with $100 \mathrm{ng} / \mathrm{ml}$ of EGF or $50 \mathrm{ng} / \mathrm{ml}$ of BDNF. Phagokinetic motility assay results were photographed at 24 and $48 \mathrm{~h}$ post treatment (A). Cells were treated with 10,100 , and $1000 \mathrm{ng} / \mathrm{ml}$ of EGF, or with 5,50 , and $500 \mathrm{ng} / \mathrm{ml}$ of BDNF. Phagokinetic motility assay results were photographed $24 \mathrm{~h}$ post treatment (B). The quantitative results are shown in a histogram. Each bar is the mean \pm SD from six independent microscopic fields of a representative experiment.

suspension ( $86 \mu 1$ stock microbeads in $30 \mathrm{ml}$ PBS) were added per well. Then the plates were centrifuged at $1200 \mathrm{rpm}$ at $4^{\circ} \mathrm{C}$ for $20 \mathrm{~min}$ and carefully transferred to incubator for at least $1 \mathrm{~h}$ at $37^{\circ} \mathrm{C}$. Medium $(1.8 \mathrm{ml})$ were removed from each well and 1500 freshly trypsinized cells in $2 \mathrm{ml}$ assay-medium (DMEM supplemented with a $0.05 \%$ fetal bovine serum) were seeded per well. Cells with or without treatments were cultured, and cell migration was photographed $24 \mathrm{~h}$ and $48 \mathrm{~h}$ post treatment.

\section{Results}

EGF and BDNF induce cell migration in human Caov3 cells. Both EGF and BDNF are known to have important functions in cell migration $(28,29)$. To investigate whether those two factors promote cell migration in human ovarian cells in culture, we treated cells with EGF or BDNF in various times and concentrations and used phagokinetic track motility assay to measure cell migration. The results showed that both EGF and BDNF induced Caov3 cell migration in a time- and dosedependent manner (Fig. 1).
EGF and BDNF induce cell proliferation and survival in human Caov3 cells. Both EGF and BDNF bind to and activate their tyrosine kinase receptor, EGFR and TrkB respectively, initiating intracellular signaling and promoting cell survival and proliferation $(30,31)$. We then investigated whether EGF and BDNF treatments affect cell survival and proliferation in human ovarian cancer cells. Cells were cultured in 12-well plates, and treated with EGF or BDNF at various time-points and concentrations. Microscopic data indicated that both EGF and BDNF induced cell proliferation and survival in human Caov3 cells in a time- and dose-dependent manner (Fig. 2).

EGF and BDNF transactivate TrkB and EGFR respectively in human Caov3 cells. Activation and/or overexpression of tyrosine protein kinase $\mathrm{B}$ receptor has been implicated in the survival and metastasis of certain human cancers, including neuroblastoma, colon and thyroid papillary carcinomas $(5,32,33)$. TrkB is activated through autophosphorylation upon ligand binding, while in many cases TrkB is transactivated by reagents other than ligands such as transcriptional activator 

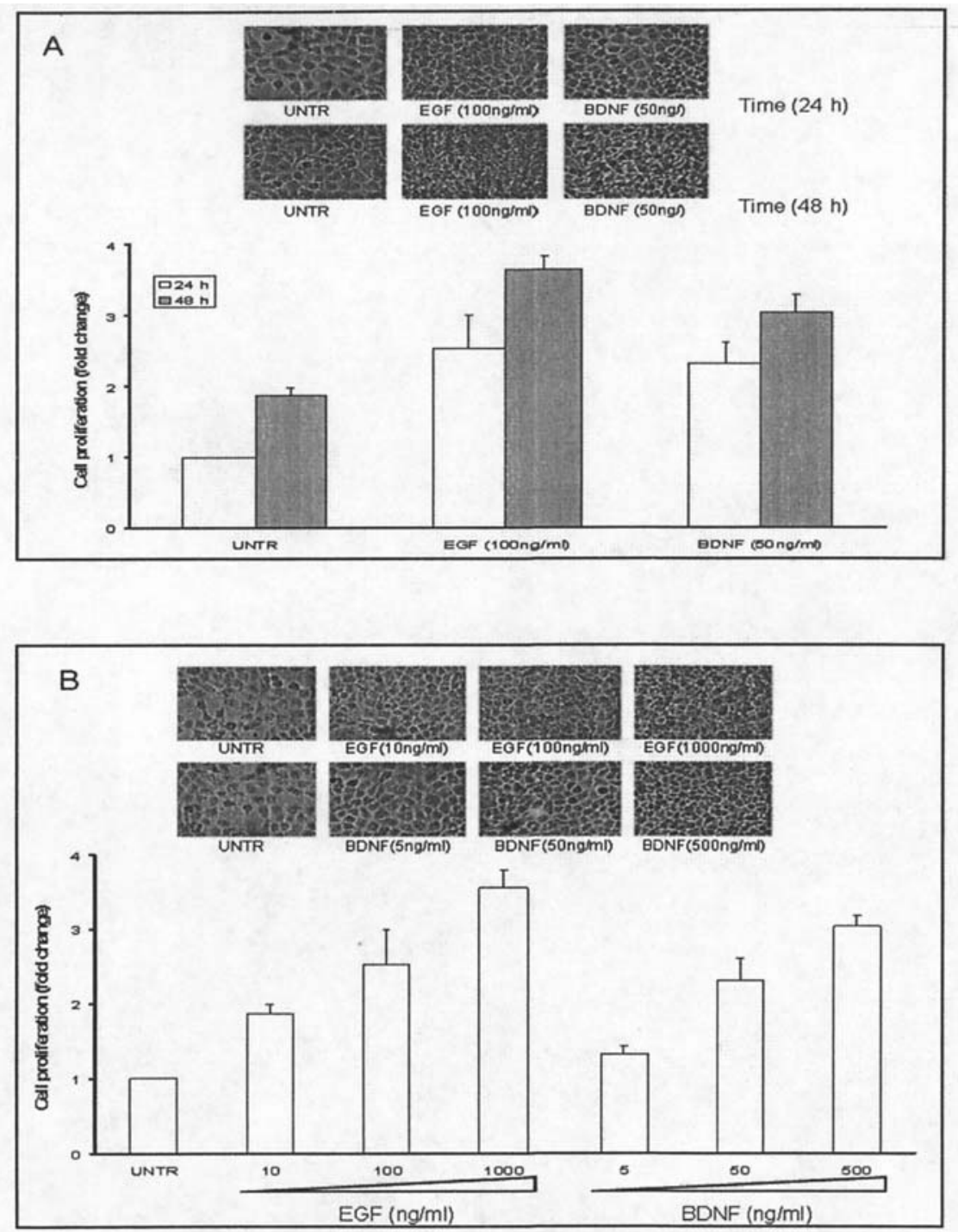

Figure 2. EGF and BDNF induce cell proliferation and survival in human Caov3 cells. Cells were seeded in 12-well plates and treated with $100 \mathrm{ng} / \mathrm{ml}$ of EGF or $50 \mathrm{ng} / \mathrm{ml}$ of BDNF. Cell densities and morphologies were photographed at 24 and $48 \mathrm{~h}$ post treatment (A). Cells were treated with 10, 100, and 1000 ng/ml of EGF, or with 5,50, and $500 \mathrm{ng} / \mathrm{ml}$ of BDNF. Cell densities and morphologies were photographed at $24 \mathrm{~h}$ post treatment (B). The quantitative results are shown in a histogram. Each bar is the mean \pm SD from six independent microscopic fields of a representative experiment.

retinoid acid, adenosine and TGF-B1 (34-37). To investigate whether survival and migration of ovarian cancer induced by EGF is mediated by both EGFR and TrkB pathway, human ovarian cancer cells were deprived of serum overnight and exposed to $100 \mathrm{ng} / \mathrm{ml} \mathrm{EGF}$ or to $50 \mathrm{ng} / \mathrm{ml} \mathrm{BDNF}$ and harvested at $5,15,30,60$, and $120 \mathrm{~min}$ post treatment. Western blot analysis using antibody recognizing phospho-EGFR and phospho-tyr490 indicated that EGF induced both EGFR and TrkB phosphorylation in a time-dependent manner. Phosphorylation of TrkB induced by EGF treatment started at $5 \mathrm{~min}$ post treatment, and the activity peaked at $15 \mathrm{~min}$ and then returned to basal level (Fig. 3B). Consistent with the published observation, phosphorylation of EGFR was rapidly and strongly induced by EGF treatment (Fig. 3A). Furthermore, phosphorylation of EGFR peaked at 60 min after BDNF treatment (Fig. 3C). As expected, the activity of TrkB peaked at 5 min after BDNF treatment (Fig. 3D).

To further explore whether EGF-induced TrkB signaling is affected by EGFR activation, we used pharmacological inhibitors of EGFR, PD153035, and TrkB, K252a. Human Caov3 cells were pretreated with PD153035 (PD1, $20 \mu \mathrm{M}$ ) or $\mathrm{K} 252 \mathrm{a}(200 \mathrm{nM})$ for $2 \mathrm{~h}$, and then treated with $100 \mathrm{ng} / \mathrm{ml}$ of EGF for 5 min. As shown in Fig. 4A and B, PD153035 significantly inhibited EGF-induced EGFR and TrkB activation, whereas K252a weakly inhibited EGF induced EGFR and TrkB activation. Meanwhile, we investigated the effects of PD153035 and K252a on BDNF-induced EGFR and TrkB activation. Human Caov3 cells were pretreated with PD153035 (PD1, $20 \mu \mathrm{M})$ or K252a (200 nM) for $2 \mathrm{~h}$, and then treated with $50 \mathrm{ng} / \mathrm{ml}$ of BDNF for $1 \mathrm{~h}$ and $5 \mathrm{~min}$ respectively. The results indicated that K252a blocked BDNF-induced EGFR and TrkB activation, while PD153035 partly inhibited BDNF-induced EGFR and TrkB activation (Fig. 4C and D).

EGF and BDNF induce Akt activation in human Caov3 cells. Published data demonstrate that EGF-induced cell proliferation and survival are mediated by PI3K-Akt pathways $(25,30,38)$. It was also found that TrkB-mediated neuronal survival is 


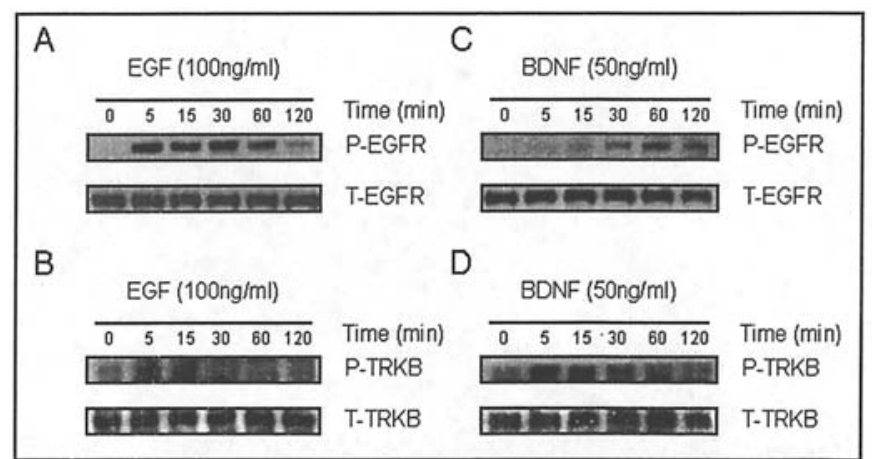

Figure 3. EGF and BDNF transactivate TrkB and EGFR respectively in human Caov3 cells. Human Caov3 cells were deprived of serum overnight and exposed to $100 \mathrm{ng} / \mathrm{ml} \mathrm{EGF}$ or to $50 \mathrm{ng} / \mathrm{ml} \mathrm{BDNF}$, and harvested at 0,5 , 15, 30, 60, and 120 min post treatment. EGFR and TrkB phosphorylation were analyzed by Western blotting.

dependent on PI3K activity (39). To examine whether EGF and BDNF activate Akt in human Caov3 cells, Caov3 cells were treated with $100 \mathrm{ng} / \mathrm{ml} \mathrm{EGF}$ or $50 \mathrm{ng} / \mathrm{ml} \mathrm{BDNF}$ and harvested at 5, 15, 30, 60, and 120 min post treatment. Western blot analysis results indicated that both EGF and BDNF induced Akt activation in a time-dependent manner. Activation of Akt was rapidly and remarkably induced at 5 min after EGF treatment, and the activity returned to basal level within 15 min. BDNF-induced Akt activation started at 5 min and peaked at $15 \mathrm{~min}$ post treatment, then returned to the basal level within 120 min (Fig. 5A and B).

To explore whether EGF- or BDNF-induced Akt activation is mediated by EGFR and TrkB kinase activity, we used EGFR inhibitor, PD153035; TrkB inhibitor, K252a; and PI3K/Akt inhibitor, LY294002. Human Caov3 cells were pretreated with PD153035 (or PD1, $20 \mu \mathrm{M}$ ), K252 (200 nM) or LY294002 (or LY, $50 \mu \mathrm{M}$ ) for $2 \mathrm{~h}$, and then treated with $100 \mathrm{ng} / \mathrm{ml}$ of EGF for $5 \mathrm{~min}$. Western blot analysis results indicated that PD153035 significantly inhibited EGF-induced Akt activation, while K252a weakly inhibited EGF-induced Akt activation (Fig. 5C). We also examined the effect of PD153035 and K252a on Akt activation induced by BDNF. Human Caov3 cells were pretreated with PD153035 $(20 \mu \mathrm{M}), \mathrm{K} 252 \mathrm{a}(200 \mathrm{nM})$

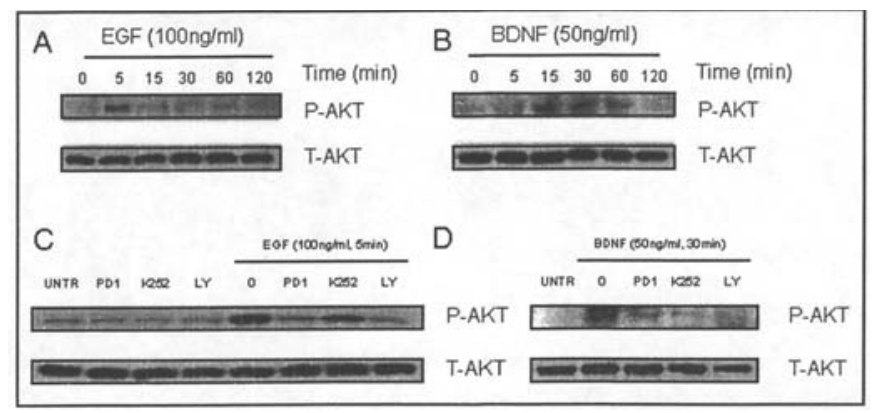

Figure 5. EGF and BDNF induce Akt activation in human Caov3 cells. Human Caov3 cells were deprived of serum overnight and exposed to $100 \mathrm{ng} / \mathrm{ml}$ EGF or to $50 \mathrm{ng} / \mathrm{ml} \mathrm{BDNF}$ and harvested at 5, 15, 30, 60, and $120 \mathrm{~min}$ post treatment. Akt phosphorylation was analyzed by Western blotting (A and B). Human Caov3 cells were pretreated with PD153035 (or PD1, $20 \mu \mathrm{M}$ ), K252a (200 nM), or LY294002 (or LY, $50 \mu \mathrm{M}$ ) for $2 \mathrm{~h}$, and then treated with EGF $(100 \mathrm{ng} / \mathrm{ml})$ and BDNF $(50 \mathrm{ng} / \mathrm{ml})$. Akt phosphorylation was analyzed by Western blotting (C and D).

or LY294002 $(50 \mu \mathrm{M})$ for $2 \mathrm{~h}$, and then treated with $50 \mathrm{ng} / \mathrm{ml}$ of BDNF for $30 \mathrm{~min}$. The results indicated that K252a completely blocked BDNF-induced Akt signaling, whereas PD153035 partly blocked BDNF-induced Akt signaling. As expected, LY294002 significantly inhibited Akt activation induced by both EGF and BDNF (Fig. 5D).

EGFR, TrkB, and PI3K/Akt inhibitors inhibit cell migration induced by EGF and BDNF in human Caov3 cells. Since our data indicate that EGFR and TrkB pathway inhibitors inhibited EGF or BDNF-induced EGFR activation, TrkB activation and Akt activation respectively, we further explored whether those inhibitors could inhibit cell migration induced by EGF and BDNF in human ovarian cancer. Cells were cultured in 12-well cell plates, EGF (100 ng/ml) or BDNF (50 ng/ml) alone or in combination with PD153035 (or PD1, $20 \mu \mathrm{M}$ ), K252a (200 nM) or LY294002 (or LY, $50 \mu \mathrm{M}$ ) were added to human Caov3 cells for $24 \mathrm{~h}$. Phagokinetic motility assay results indicated that cell migration was significantly reduced by combination of inhibitors with EGF or BDNF as compared to that by EGF or BDNF alone (Fig. 6A).

To directly examine whether inhibitors of EGFR, TrkB, and $\mathrm{PI} 3 \mathrm{~K} / \mathrm{Akt}$ could weaken cell proliferation and survival induced

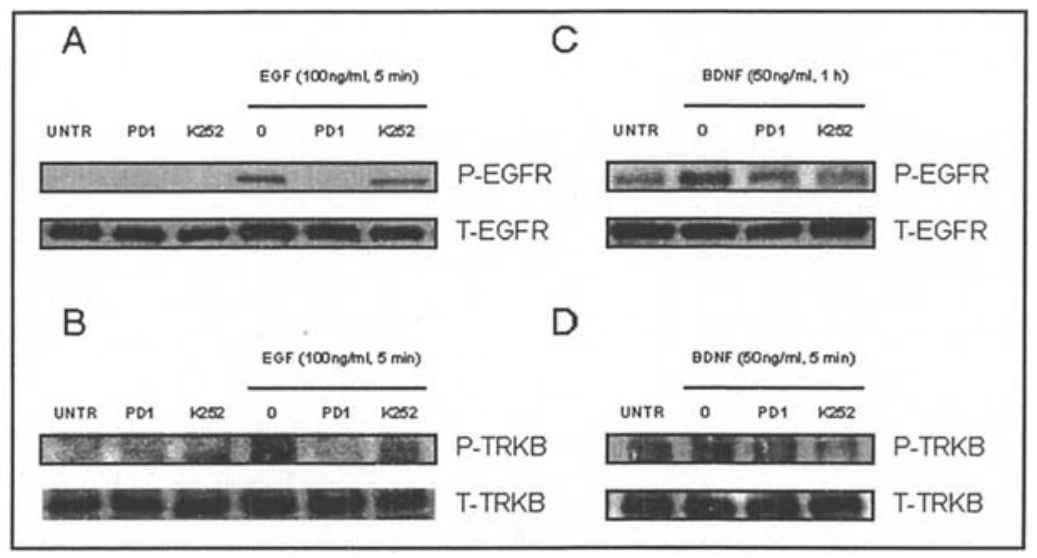

Figure 4. EGFR inhibitor and BDNF inhibitor inhibit EGF-induced TrkB and BDNF-induced EGFR activation in human Caov3 cells. Human Caov3 cells were pretreated with PD153035 $(20 \mu \mathrm{M})$ or K252a $(200 \mathrm{nM})$ for $2 \mathrm{~h}$, and then treated with $100 \mathrm{ng} / \mathrm{ml}$ of EGF and $50 \mathrm{ng} / \mathrm{ml}$ of BDNF as shown. EGFR and BDNF phosphorylation were analyzed by Western blotting. 

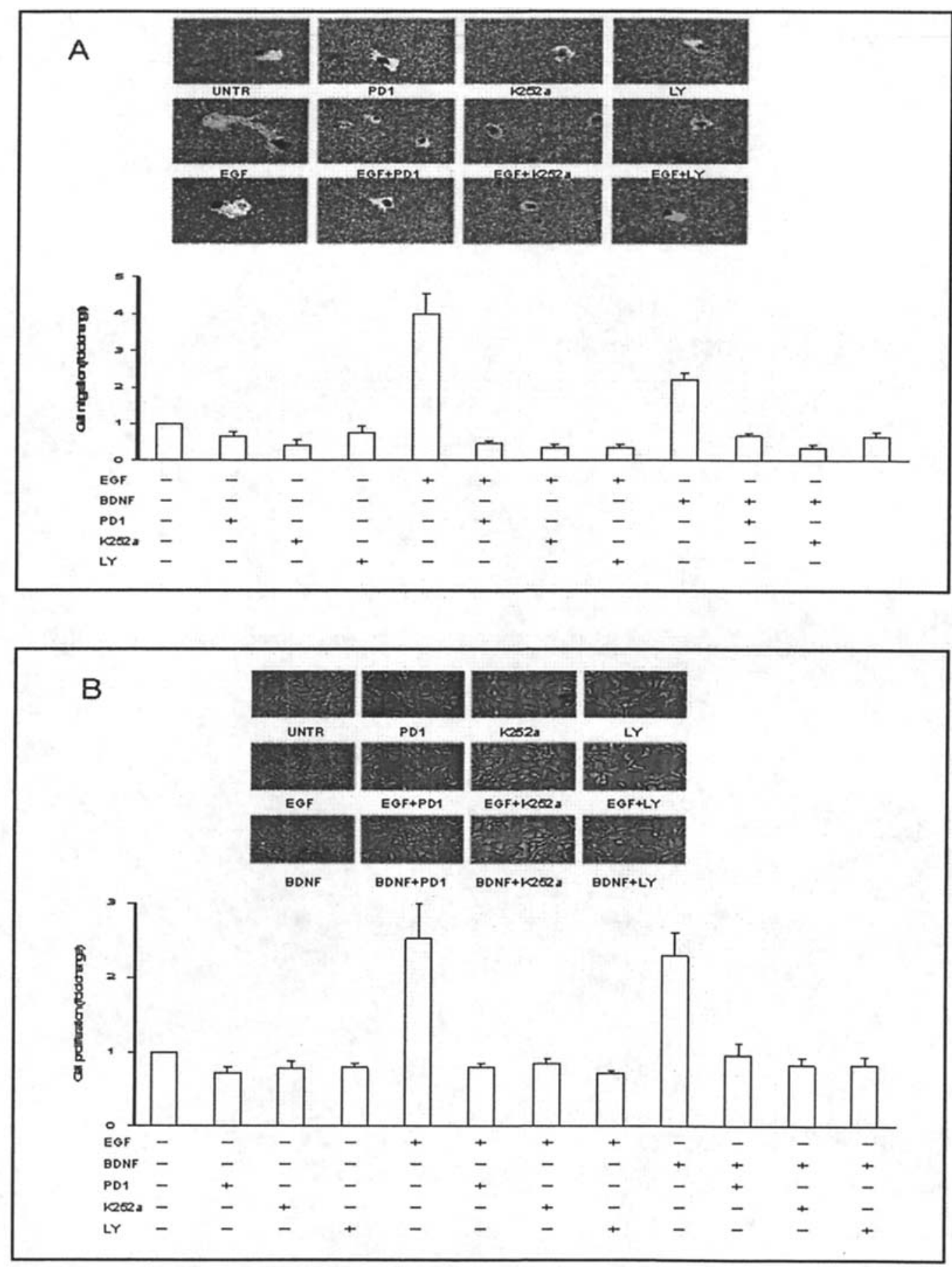

Figure 6. EGFR, TrkB, and PI3K/Akt inhibitors inhibit cell migration induced by EGF and BDNF in human Caov3 cells. Cells were treated with $100 \mathrm{ng} / \mathrm{ml}$ of EGF or $50 \mathrm{ng} / \mathrm{ml}$ of BDNF alone or in combination with PD153035 (or PD1, $20 \mu \mathrm{M}$ ), K252a (200 nM) or LY294002 (or LY, $50 \mu \mathrm{M}$ ). Phagokinetic motility assay results were photographed at $24 \mathrm{~h}$ post treatment. The quantitative results are shown in a histogram. Each bar is the mean \pm SD from six independent microscopic fields of a representative experiment (A). Cells were cultured in 12-well cell culture plates, EGF (100 ng/ml) or BDNF (50 ng/ml) alone or in combination with PD153035 (or PD1, $20 \mu \mathrm{M}$ ), K252a (200 nM) or LY294002 (or LY, $50 \mu \mathrm{M}$ ) were added to human Caov3 cells. Cell densities and morphologies were photographed at $24 \mathrm{~h}$ post treatment. The quantitative results are shown in a histogram. Each bar is the mean \pm SD from six independent microscopic fields of a representative experiment (B).

by EGF and BDNF in human ovarian cancer, cells were cultured in 12-well cell culture plates, EGF $(100 \mathrm{ng} / \mathrm{ml})$ or BDNF (50 ng/ml) alone or in combination with PD153035 (or PD1, $20 \mu \mathrm{M}$ ), K252a (200 nM) or LY294002 (or LY, $50 \mu \mathrm{M}$ ) were added to human Caov3 cells for $24 \mathrm{~h}$. Microscopic data indicated that the cell proliferation and survival rate was significantly reduced by combination of inhibitors with EGF or BDNF as compared with that by EGF or BDNF alone (Fig. 6B).
EGFR is required for EGF-induced cell migration. The above data indicate that EGFR plays an important role in EGFinduced cell migration, and inhibition of EGFR-mediated cell signaling could reduce EGF-induced cell migration. To further examine whether EGFR is required for EGF-induced cell migration, EGFR knockout cells were used. EGFR ${ }^{+/+}$and EGFR $^{-/-}$MEF cells were treated with mouse EGF $(100 \mathrm{ng} / \mathrm{ml})$ with or without various inhibitors. Phagokinetic motility 

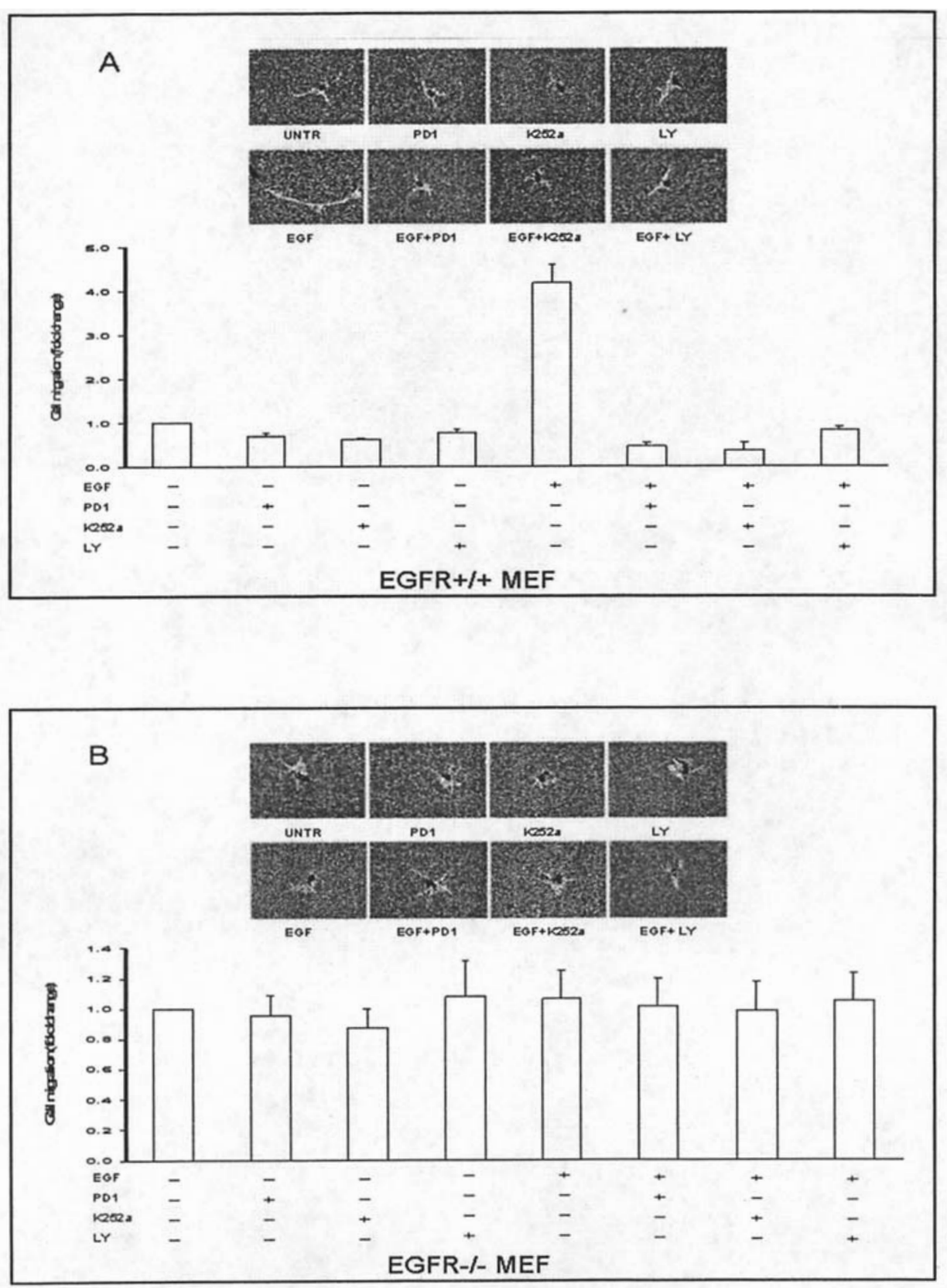

Figure 7. EGFR is required for EGF-induced cell migration. EGFR +/+ and -/- MEF cells were treated with mouse EGF (100 ng/ml) alone or in combination with PD153035 (or PD1, $20 \mu \mathrm{M}$ ), K252a (200 nM) or LY294002 (or LY, $50 \mu \mathrm{M}$ ). Phagokinetic motility assay results were photographed at $24 \mathrm{~h}$ after treatment. The quantitative results are shown in a histogram. Each bar is the mean \pm SD from six independent microscopic fields of a representative experiment.

assay results demonstrated that EGFR wild-type cells treated with EGF showed much more cell migration than EGFR knockout cells. As expected, EGFR inhibitor significantly reduced EGF-induced cell migration in wild-type cells (Fig. 7).

\section{Discussion}

As noted in previous studies (5-9), BDNF plays important roles in regulating proliferation, survival and differentiation of CNS neurons and the peripheral nervous system (PNS). Recent evidence suggests that BDNF and its TrkB receptor might be important in regulating tumor growth and metastasis $(5,40)$. In basal cell carcinoma and cutaneous squamous cell carcinoma, increased levels of nerve growth factor and TrkA, $\mathrm{B}$, and $\mathrm{C}$ may reflect unique survival pathways. Higher levels of expression of Trk receptors in cutaneous squamous cell carcinoma cells may predict perineural invasion (41). Constitutive expression of BDNF and variable expression of its receptor trkB are frequently detected in tumors from patients with a poor prognosis $(28,42)$. The data presented here indicate that BDNF induced cell migration, proliferation and survival in human Caov3 cells.

It was found that during brain development BDNF activates ERK and PI3K/Akt pathways $(17,43)$. TrkB-mediated neuronal survival is dependent on PI3K and to a lesser extent MEK activity, while growth depends upon both MEK and PI3K activity (39). Previous studies showed that phosphorylation of BDNF receptor TrkB, PI3K and Akt, a target of PI3K, in the hippocampus increased in parallel with spatial memory formation. When spatial learning was inhibited by antisense 
BDNF oligodeoxynucleotide, the activation was diminished. Chronic treatment with PI3K inhibitor wortmannin impaired spatial learning, suggesting that activation of TrkB/PI3K and protein synthesis signaling pathway by BDNF in the hippocampus is important for spatial memory (44). The ability of BDNF to rescue the cells from cisplatin-induced cell death was also inhibited by treatment with Trk tyrosine kinase inhibitor, K252a, and PI3K/Akt inhibitor, LY294002, suggesting that activation of TrkB pathway through PI3K is required for BDNF's survival-promoting effects (43). Our results show that BDNF rapidly activated TrkB and Akt signaling in human Caov3 cells. TrkB inhibitor dramatically inhibited BDNF-induced TrkB and Akt activation, suggesting that TrkB signaling operates via activation of PI3K/Akt pathway.

Peptide growth factors regulate normal cellular proliferation and differentiation through autocrine and paracrine pathways and are involved in cancer development and progression. Our results that EGF promoted cell migration, proliferation and survival in human Caov3 cells are consistent with those presented previously $(45,46)$. EGF binds to and activates its tyrosine kinase receptor, EGFR. EGFR activation is not only important in normal cellular processes, but it is frequently altered or overexpressed in many malignancies. EGFR overexpression and activation result in increased proliferation and migration of solid tumors including ovarian cancer $(23,24,26,47)$. Activation of EGFR tyrosine kinase results in activation of a number of intracellular signals, which culminate in not only cell proliferation but also other processes that are crucial to cancer progression, including angiogenesis, metastasis, and inhibition of apoptosis. These events are mediated through various downstream targets of EGFR (e.g. the serine/threonine kinase Raf and MEK-ERK 1/2). Activation of EGFR also results in activation of lipid kinase PI3K, generating the second messenger phosphatidylinositol 3,4,5trisphosphate, which in turn activates Akt. In our experiments, both EGF and BDNF induced EGFR activation in human Caov3 cells. Our results are in agreement with previous studies which revealed that EGFR signaling operates via activation of the PI3K-Akt pathway $(48,49)$. To our surprise, activation of TrkB can also occur via EGFR. However, TrkB activation induced by EGF displays different kinetics compared with that induced by BDNF. EGF and BDNF induced TrkB phosphorylation within $5 \mathrm{~min}$ but maximal activation by EGF was observed at $15 \mathrm{~min}$, while that by BDNF was observed at $5 \mathrm{~min}$. EGF-mediated activation of TrkB was completely blocked by the EGFR inhibitor, PD153035 and partially blocked by the TrkB, K252a. In contrast, BDNF-induced TrkB phosphorylation was completely blocked by K252a and partially blocked by PD153035. Therefore, our data indicated the requirement of EGFR for activation of TrkB by either EGF or BDNF.

Crosstalk between heterologous cellular signaling systems has now emerged as a common principle emphasizing that most biological responses result from functional integration of a specific and diverse network of intercellular signaling pathways (50). In the present study we also demonstrated that there is crosstalk between EGFR and TrkB. Signaling of both EGFR and TrkB operates via activation of PI3K/Akt pathway affecting cell proliferation and cell survival. Akt phosphorylation induced by EGF was completely blocked by the EGFR inhibitor, PD153035, and PI3K/Akt inhibitor, LY294002, and partially blocked by the TrkB inhibitor, K252a. However, BDNF-induced activation of Akt was completely blocked by K252a and LY294002, and partially blocked by PD153505. Therefore, PI3K/Akt pathway is co-activated by EGFR and TrkBs. Furthermore, PD153505, K252a, and LY294002 had antimetastatic and antiproliferative effects on human Caov3 ovarian cancer cell lines in vitro. All of them inhibited cell migration, proliferation and survival induced by EGF or BDNF. It was reported that co-expression of EGF-related proteins is associated with advanced stage in serous and clear cell carcinoma (51), and there are a variety of growth regulators in vivo. Thus our report suggests that functional crosstalk between EGFR and TrkB pathways could have potential therapeutic implications. EGFR knockout cells are much less sensitive to EGF treatment, suggesting that EGFR is required for cell migration and an EGFR inhibitor, such as PD153035, might be the better choice among other potential therapeutic agents.

In conclusion, our present study provides for the first time evidence that EGFR and TrkB crosstalk each other and enhance ovarian cancer cell invasiveness, proliferation and survival. Our data suggest that a combination of inhibitors of EGFR and TrkB with inhibitors of cell survival pathways could yield a better outcome in the clinical treatment of ovarian cancer.

\section{Acknowledgements}

This research was supported in part by a grant from National Natural Science Foundation of China, a grant from NIH (P20 RR016457 from INBRE Program of the National Center for Research Resources) and a grant for biomedical research from Rhode Island Foundation, and a grant from Slater Center for Environmental Biotechnology.

\section{References}

1. Penson RT, Shannon KE, Sharpless NE and Seiden MV: Ovarian cancer: an update on genetics and therapy. Compr Ther 24: 477-487, 1998.

2. Hanahan D and Weinberg RA: The hallmarks of cancer. Cell 100: 57-70, 2000.

3. Frisch SM and Ruoslahti E: Integrins and anoikis. Curr Opin Cell Biol 9: 701-706, 1997.

4. Frisch SM and Screaton RA: Anoikis mechanisms. Curr Opin Cell Biol 13: 555-562, 2001.

5. Douma S, van Laar T, Zevenhoven J, Meuwissen R and van Garderen E and Peeper DS: Suppression of anoikis and induction of metastasis by the neurotrophic receptor TrkB. Nature 430: 1034-1039, 2004.

6. Danzer SC, Pan E, Nef S, Parada LF and McNamara JO: Altered regulation of brain-derived neurotrophic factor protein in hippocampus following slice preparation. Neuroscience 126: 859-869, 2004.

7. Backstrom A, Soderstrom S, Kylberg A and Ebendal T: Molecular cloning of the chicken trkA and its expression in early peripheral ganglia. J Neurosci Res 46: 67-81, 1996.

8. Glass DJ, Nye SH, Hantzopoulos P, Macchi MJ, Squinto SP, Goldfarb M and Yancopoulos GD: TrkB mediates BDNF/NT-3dependent survival and proliferation in fibroblasts lacking the low affinity NGF receptor. Cell 66: 405-413, 1991.

9. Husson I, Rangon CM, Lelievre V, Bemelmans AP, Sachs P, Mallet J, Kosofsky BE and Gressens P: BDNF-induced white matter neuroprotection and stage-dependent neuronal survival following a neonatal excitotoxic challenge. Cereb Cortex 15: 250-261,2005. 
10. Nakagawara A, Azar CG, Scavarda NJ and Brodeur GM: Expression and function of TRK-B and BDNF in human neuroblastomas. Mol Cell Biol 14: 759-767, 1994.

11. Aoyama M, Asai K, Shishikura T, Kawamoto T, Miyachi T, Yokoi T, Togari H, Wada Y, Kato T and Nakagawara A: Human neuroblastomas with unfavorable biologies express high levels of brain-derived neurotrophic factor mRNA and a variety of its variants. Cancer Lett 164: 51-60, 2001

12. Eggert A, Grotzer MA, Ikegaki N, Zhao H, Cnaan A, Brodeur GM and Evans AE: Expression of the neurotrophin receptor TrkB is associated with unfavorable outcome in Wilms' tumor. J Clin Oncol 19: 689-696, 2001

13. Brodeur GM: Neuroblastoma: biological insights into a clinical enigma. Nat Rev Cancer 3: 203-216, 2003.

14. Ho R, Eggert A, Hishiki T, Minturn JE, Ikegaki N, Foster P, Camoratto AM, Evans AE and Brodeur GM: Resistance to chemotherapy mediated by TrkB in neuroblastomas. Cancer Res 62: 6462-6466, 2002

15. Scala S, Wosikowski K, Giannakakou P, Valle P, Biedler JL, Spengler BA, Lucarelli E, Bates SE and Thiele CJ: Brain-derived neurotrophic factor protects neuroblastoma cells from vinblastine toxicity. Cancer Res 56: 3737-3742, 1996.

16. Cheng L, Sapieha P, Kittlerova P, Hauswirth WW and Di Polo A: TrkB gene transfer protects retinal ganglion cells from axotomyinduced death in vivo. J Neurosci 22: 3977-3986, 2002.

17. Climent E, Pascual M, Renau-Piqueras J and Guerri C: Ethanol exposure enhances cell death in the developing cerebral cortex: role of brain-derived neurotrophic factor and its signaling pathways. J Neurosci Res 68: 213-225, 2002.

18. Hu P and Kalb RG: BDNF heightens the sensitivity of motor neurons to excitotoxic insults through activation of TrkB. J Neurochem 84: 1421-1430, 2003.

19. Kim H, Li Q, Hempstead BL and Madri JA: Paracrine and autocrine functions of brain-derived neurotrophic factor (BDNF) and nerve growth factor (NGF) in brain-derived endothelial cells. J Biol Chem 279: 33538-33546, 2004.

20. Marsh HN, Scholz WK, Lamballe F, Klein R, Nanduri V, Barbacid M and Palfrey HC: Signal transduction events mediated by the BDNF receptor gp 145trkB in primary hippocampal pyramidal cell culture. J Neurosci 13: 4281-4292, 1993.

21. Barnabe-Heider F and Miller FD: Endogenously produced neurotrophins regulate survival and differentiation of cortical progenitors via distinct signaling pathways. J Neurosci 23: 5149-5160, 2003

22. Jaboin J, Kim CJ, Kaplan DR and Thiele CJ: Brain-derived neurotrophic factor activation of TrkB protects neuroblastoma cells from chemotherapy-induced apoptosis via phosphatidylinositol 3'-kinase pathway. Cancer Res 62: 6756-6763, 2002.

23. Jorissen RN, Walker F, Pouliot N, Garrett TP, Ward CW and Burgess AW: Epidermal growth factor receptor: mechanisms of activation and signalling. Exp Cell Res 284: 31-53, 2003.

24. Earp HS, Dawson TL, Li X and Yu H: Heterodimerization and functional interaction between EGF receptor family members: a new signaling paradigm with implications for breast cancer research. Breast Cancer Res Treat 35: 115-132, 1995.

25. Yarden Y and Sliwkowski MX: Untangling the ErbB signalling network. Nat Rev Mol Cell Biol 2: 127-137, 2001

26. Alper O, Bergmann-Leitner ES, Bennett TA, Hacker NF, Stromberg K and Stetler-Stevenson WG: Epidermal growth factor receptor signaling and the invasive phenotype of ovarian carcinoma cells. J Natl Cancer Inst 93: 1375-1384, 2001.

27. Qiu L, Di W, Jiang Q, Scheffler E, Derby S, Yang J, Kouttab N, Wanebo H, Yan B and Wan Y: Targeted inhibition of transient activation of the EGFR-mediated cell survival pathway enhances paclitaxel-induced ovarian cancer cell death. Int J Oncol 27: $1441-1448,2005$

28. Matsumoto K, Wada RK, Yamashiro JM, Kaplan DR and Thiele CJ: Expression of brain-derived neurotrophic factor and p145TrkB affects survival, differentiation, and invasiveness of human neuroblastoma cells. Cancer Res 55: 1798-1806, 1995.

29. Ma D and Niederkorn JY: Role of epidermal growth factor receptor in the metastasis of intraocular melanomas. Invest Ophthalmol Vis Sci 39: 1067-1075, 1998.

30. Gschwind A, Fischer OM and Ullrich A: The discovery of receptor tyrosine kinases: targets for cancer therapy. Nat Rev Cancer 4: 361-370, 2004.

31. Sugimoto T, Kuroda H, Horii Y, Moritake H, Tanaka T and Hattori S: Signal transduction pathways through TRK-A and TRK-B receptors in human neuroblastoma cells. Jpn J Cancer Res 92: 152-160, 2001
32. Schulte JH, Schramm A, Klein-Hitpass L, Klenk M, Wessels H, Hauffa BP, Eils J, Eils R, Brodeur GM, Schweigerer L, Havers W and Eggert A: Microarray analysis reveals differential gene expression patterns and regulation of single target genes contributing to the opposing phenotype of TrkA- and TrkBexpressing neuroblastomas. Oncogene 24: 165-177, 2005.

33. Coulier F, Kumar R, Ernst M, Klein R, Martin-Zanca D and Barbacid M: Human trk oncogenes activated by point mutation, in-frame deletion, and duplication of the tyrosine kinase domain. Mol Cell Biol 10: 4202-4210, 1990.

34. Sometani A, Kataoka H, Nitta A, Fukumitsu H, Nomoto H and Furukawa S: Transforming growth factor-beta1 enhances expression of brain-derived neurotrophic factor and its receptor, TrkB, in neurons cultured from rat cerebral cortex. J Neurosci Res 66: 369-376, 2001

35. Lee FS, Rajagopal R and Chao MV: Distinctive features of Trk neurotrophin receptor transactivation by $\mathrm{G}$ protein-coupled receptors. Cytokine Growth Factor Rev 13: 11-17, 2002.

36. Mey J and Rombach N: Retinoic acid increases BDNF-dependent regeneration of chick retinal ganglion cells in vitro. Neuroreport 10: 3573-3577, 1999

37. Ruiz-Leon Y and Pascual A: Induction of tyrosine kinase receptor $B$ by retinoic acid allows brain-derived neurotrophic factor-induced amyloid precursor protein gene expression in human SH-SY5Y neuroblastoma cells. Neuroscience 120: 1019-1026, 2003

38. Seidman R, Gitelman I, Sagi O, Horwitz SB and Wolfson M The role of ERK 1/2 and p38 MAP-kinase pathways in taxolinduced apoptosis in human ovarian carcinoma cells. Exp Cell Res 268: 84-92, 2001.

39. Atwal JK, Massie B, Miller FD and Kaplan DR: The TrkB-Shc site signals neuronal survival and local axon growth via MEK and P13-kinase. Neuron 27: 265-277, 2000.

40. Chiappa SA, Chin LS, Zurawel RH and Raffel C: Neurotrophins and Trk receptors in primitive neuroectodermal tumor cell lines. Neurosurgery 45: 1148-1154, 1999.

41. Chen-Tsai CP, Colome-Grimmer M and Wagner RF Jr: Correlations among neural cell adhesion molecule, nerve growth factor, and its receptors, TrkA, TrkB, TrkC, and p75, in perineural invasion by basal cell and cutaneous squamous cell carcinomas. Dermatol Surg 30: 1009-1016, 2004

42. Lucarelli E, Kaplan D and Thiele CJ: Activation of trk-A but not trk-B signal transduction pathway inhibits growth of neuroblastoma cells. Eur J Cancer 33: 2068-2070, 1997.

43. Jaboin J, Hong A, Kim CJ and Thiele CJ: Cisplatin-induced cytotoxicity is blocked by brain-derived neurotrophic factor activation of TrkB signal transduction path in neuroblastoma. Cancer Lett 193: 109-114, 2003.

44. Mizuno M, Yamada K, Takei N, Tran MH, He J, Nakajima A, Nawa $\mathrm{H}$ and Nabeshima T: Phosphatidylinositol 3-kinase: a molecule mediating BDNF-dependent spatial memory formation. Mol Psychiatry 8: 217-224, 2003.

45. Ciardiello F and Tortora G: Interactions between the epidermal growth factor receptor and type I protein kinase A: biological significance and therapeutic implications. Clin Cancer Res 4: 821-828, 1998.

46. Kelly-Spratt KS, Klesse LJ and Parada LF: BDNF activated TrkB/IRR receptor chimera promotes survival of sympathetic neurons through Ras and PI-3 kinase signaling. J Neurosci Res 69: 151-159, 2002.

47. Andl CD, Mizushima T, Nakagawa H, Oyama K, Harada H, Chruma K, Herlyn M and Rustgi AK: Epidermal growth factor receptor mediates increased cell proliferation, migration, and aggregation in esophageal keratinocytes in vitro and in vivo. $\mathrm{J}$ Biol Chem 278: 1824-1830, 2003.

48. Citri A, Kochupurakkal BS and Yarden Y: The achilles heel of ErbB-2/HER2: regulation by the Hsp90 chaperone machine and potential for pharmacological intervention. Cell Cycle 3: 51-60, 2004 .

49. Nicosia SV, Bai W, Cheng JQ, Coppola D and Kruk PA: Oncogenic pathways implicated in ovarian epithelial cancer. Hematol Oncol Clin North Am 17: 927-943, 2003.

50. Hur EM and Kim KT: G protein-coupled receptor signalling and cross-talk: achieving rapidity and specificity. Cell Signal 14: 397-405, 2002.

51. Baron AT, Lafky JM, Boardman CH, Balasubramaniam S, Suman VJ, Podratz KC and Maihle NJ: Serum sErbB1 and epidermal growth factor levels as tumor biomarkers in women with stage III or IV epithelial ovarian cancer. Cancer Epidemiol Biomarkers Prev 8: 129-137, 1999. 